\title{
Sustainable Development of Russian Regions on the Basis of Knowledge Diffusion: Empirical Analysis
}

\author{
Alexei Koritsky \\ Novosibirsk State Technical University, \\ School of Business \\ Novosibirsk, Russia \\ koritskiy-a@mail.ru
}

\author{
Anna Aletdinova \\ Novosibirsk State Technical University, \\ Department of automation and computer engineering \\ Novosibirsk, Russia \\ aletdinova@corp.nstu.ru
}

\author{
Alexandr Babkin \\ Peter the Great St.Petersburg Polytechnic University \\ St. Petersburg, Russia \\ babkin@spbstu.ru
}

\begin{abstract}
One of the important factors in ensuring sustainable development of countries is the possibility of obtaining knowledge by the population, but knowledge diffusion is not universal, it is influenced by regional features. The indicator of it is the assessment of the regional impact of human capital, which will be proven to be influenced by the density and level of employment in Russia. The paper shows the dependence of the population income on the regional characteristics, estimates of the impact of human capital are demonstrated. The regression analysis based on the Cobb-Douglas model is used as the method of research, and the relative capital armament of labor, the density of employment, the average level of education in the economy, the share of employed with higher education in the total number of employees are taken as exogenous variables. The income of the population was considered as an exogenous variable. The authors assumed that in regions with higher population densities the impact of human capital (and hence the knowledge diffusion) is higher, so the regions are grouped by this indicator into European (high) and Asian (low) regions. The growth of the employment density by $1 \%$ corresponds to the growth of income per employee by about $0.02-0.03 \%$, therefore, the doubling of the employment density is accompanied by the increase in income by $2-3 \%$. At the same time, the coefficient of elasticity of impact of human capital was lower than the coefficient of elasticity of impact of the relative capital-labor ratio. It can be assumed that the income is less affected by human capital than physical capital. Regression spatial analysis has shown that in the regions of the European part of Russia the impact of physical and human capital is higher than in the regions of the Asian part, which means that investment in physical capital is more appropriate to be placed mainly in more densely populated regions, but this does not solve the problem of ensuring access to knowledge and realization of its potential.
\end{abstract}

Keywords-sustainable development; knowledge diffusion; human capital; impact of education; the density of employment; agglomeration effects; physical capital and regional characteristics capital-labor ratio; elasticity coefficients

\section{INTRODUCTION}

Speaking about sustainable development, we always consider three areas that ensure joint goals of harmonious interaction between a man and the biosphere: the economy (which gives economic efficiency, the implementation of an inclusive business model, improving environmental safety, the development of new breakthrough technologies, improving the quality of life of the population); ecology (controlling and regulating the harming of the environment, the inhabitants of the planet); society (solving the problem of hunger, trying to realize the potential of all the inhabitants of the planet on equal rights).

In recent decades, the analysis of the peculiarities and impact of knowledge diffusion on the well-being of society as one of the main factors of sustainable development has attracted increasing attention of economists from different countries. Reviews of these studies are contained in the works of such scientists as E. Pelinescu, L. Wantchekon, M. Klašnja, N. Novta, A. C. Teixeira, A. S. S. Queirós [1, 2, 3]. They consider studies of the causes and knowledge diffusion, their assessment through the norms of the impact of education, the impact of human capital on economic development and income differentiation, both at the microeconomic level (the level of individuals and firms) and at the macroeconomic level (the level of regions and countries).

This paper focuses on the analysis of regional effects, in particular, on urban and rural agglomerations, in the dependence of the differentiation of incomes of the population of the Russian regions from human capital, expressed through the indicators of "the average level of education of one person employed in the economy of the region" or "the share of the employed with higher education of the total number of employed in the economy of the region".

Sustainable development of territories depends on the processes of knowledge accumulation, so it is useful to study 
them at the micro level - inside agglomerations, to assess their impact on labor productivity and income levels of the population, when a large number of agglomerations provide socio-economic development of regions, and the population benefits from living in large cities or agglomerations. The level of education of the population is one of the main indicators characterizing the accumulation of human capital in the regions. It should be noted that, despite the labor interregional migration, including graduates, knowledge in the space is spread not evenly and everywhere, and the reason for it should be sought in the effects formed by agglomerations.

Thus, the purpose of this article is relevant, namely, to identify the impact of regional features, including the density of employment, on the formation of income, and the return of human capital in the regions of Russia.

\section{MATERIALS AND METHODS}

\section{A. Related Work}

Adam Smith also wrote about the importance of the capacity of markets for the development of the social division of labor, for the specialization of production and productivity. It is obvious that firms are larger and are able to take advantage of the positive effects of scale production in wellpopulated countries and regions, and are particularly effective in large urban agglomerations. The research of Laursen K., Reichstein T., A. Salter shows that the decision of companies to cooperate with universities is based on two factors: their geographical proximity and rating [4]. V. Tselios, A. Rovolis, Y. Psycharis define the influence on the accumulation of human capital of the physical geography of regions and the distance between economic agents [5]. F. Sbergami writes about the existence of positive interrelations between economic growth and geographical agglomeration, which have already been widely documented by historians [6, p.1]. Here you can find examples of works by V. Tselios, A. Rovolis, Y. Psycharis, A. Faggian, P. McCann, B. Abbott et al. [5, 7, 8]. F. Sbergami believes that a large role in long-term economic growth is played by the "spraying" of knowledge and technological externalities, which is reflected in all major models of endogenous growth [6, p.3.1]. As shown by $\mathrm{I}$. Eaton, S. Kortum, technological externalities are associated with the location of economic and research activity [10]. F. Sbergami implies the existence of a positive relationship between the clustering of industry, research activity and growth processes [6, p.1]. Indeed, cities and urban agglomerations in Russia are, as a rule, the centres of industry, especially high-tech, innovation, research and educational activities. But cities also historically arise in regions with rather high density of the population. P. Martin and G. Ottaviano showed that economic growth and agglomeration were mutually reinforcing processes [10, p.1].

Scientists, engaged in empirical research of knowledge diffusion and human capital, use the duration of fundamental education as one of the main criteria for its formation. For example, P. Klenow and A. Rodriguez-Clare assessed human capital taking into account the average number of years of study, the analysis of the impact of education on earnings showed differences in income per employee in the form of the following components: physical capital, human capital and TPF (total productivity factors) [11]. However, with other factors being equal, gender differences have more influential power, men with classical education in Russia earn $6.8 \%$ more than women [12].

K. Goldin and L. Katz showed on the example of the United States that during the 20th century about $25 \%$ growth in the income level of the employee was due to the increase in the level of education [12]. D. Mitch revealed the dependence of economic growth on the spread of secondary and higher education in the 20th century in Europe [13]. A. Young showed how the increase in the duration of basic education played a role in the economic development of the newly industrialized countries of Asia [14]. As R.E. Lucas writes, "When we talk about differences in technology between countries, we mean not knowledge at all, but knowledge of specific people or specific people's subcultures" [15]. C. Jones found that "increasing levels of education and training (reflected in the increase in the average training period of four years between 1950 and 1993) stimulates growth of over $30 \%$ time performance" [16].

The reasons for the higher economic activity in urban agglomerations are explained by the accumulation of social, human, industrial and scientific capital, formed by the system of cultural values, a higher rate of information diffusion. The income growth in agglomerations is provided for by a positive effect of the scale of production in industry, in-depth social division of labor, developing due to the greater capacity of labor markets and goods in well-populated and urbanized regions. They generate economies of scale in services production, trade, education, and a more intense diffusion of new knowledge and technologies, contributing to the emergence and diffusion of innovation.

This article is a continuation of the authors' work [18, 20], which shows a positive relationship between the capacity of the regional market and the level of education of the employed population with the average monthly wage of the population employed in the economy of the region. There are also significantly higher rates of the impact of human capital (level of education) in the set of regions, including megalopolises in comparison with the same set of regions, but without these megalopolises. At the same time, the negative statistical correlation between the density of employment and the average monthly wage in the region was revealed.

It is possible to assume that in more densely populated and urbanized regions there is also more acute competition in labor markets. In addition, Russia continues to operate a compensatory mechanism in which in regions with difficult and unfavorable natural and climatic conditions there are increasing coefficients to wages.

\section{B. The Method of Empirical Research}

In the Russian Federation, the population density was 8.6 people / $\mathrm{m} 2$, almost the same level in Northwestern Federal District. In the Central and North Caucasus Districts the population density is more than 40 people/m2, in the Southern and Volga Federal Districts - more than 20 people / $\mathrm{m} 2$. The lowest levels of this indicator are in the Ural, Siberian and Far 
Eastern Federal districts. Based on this information, the authors divided the Russian regions into two major groups: the 1st group includes the regions of the European part of Russia, that is CF, NWFD, VFD, SFD and NCFD, the 2nd group includes the "Asian" regions, i.e. regions included in the Ural, Siberian and Far Eastern Federal Districts. But due to the differences in demographic situations in the regions and unemployment rates, the variable "density of employment" is taken as one of the regressors, according to the authors, it better characterizes the intensity of economic activity in the regions and the possibility of social division of labor in them.

The variable "density of employment" characterizes the degree of development of the territory of the regions and natural and climatic conditions of life in the regions associated with it. It is possible to assume that the density of employment also characterizes the opportunities of regions to realize positive effects of scales of production, to develop and deepen public division of work, specialization and cooperation in the production of goods. In addition to these positive effects, the diffusion of knowledge and technology is more active in more densely populated regions, since people's production and social contacts there are less difficult as there are no such long distances, it can be assumed that in such regions they master new technologies faster and the level of technology used is higher. Accordingly, in these regions productivity and income of the population should be higher.

To assess the impact of physical and human capital, as well as the density of employment on the incomes of the population of the regions, the macroeconomic extended CobbDouglas production function is used, the number of variables of which includes "relative capital armament of labor", "employment density" and "human capital" as factors of production:

$$
y_{i}=A k{ }_{i}^{\alpha} n_{i}^{\delta} h_{i}^{\gamma}
$$

где $A$ is the coefficient characterizing the total factor productivity; $k_{i}$ is the relative capital-labor ratio in the $i$ th region; $n_{i}$ is the density of employment in the $i$ th region; $h_{i}$ is the stock of human capital in the economy of the $i$ th region (in the form of indicators "the average level of education of one person employed in the economy of the region" and "the share of the employed with higher education of the total population employed in the economy of the region")

This form of production function is used primarily due to the simplicity of the interpretation of the coefficients at the degrees of the corresponding variables, which are the elasticity coefficients of the dependent factor in an independent variable. To determine the unknown parameters representing the influence of independent factors, using well-known formulas of least square method, the equation (1) is logarithmized. The corresponding regression equation is as follows:

$$
\ln y_{i}=\ln A+\alpha \ln k_{i}+\delta \ln n_{i}+\gamma \ln h_{i}+\varepsilon_{i}
$$

To increase the statistical reliability of the estimates of regression equations, data for four-year periods are combined into single data arrays. The average monthly incomes per one person employed for different years are presented in a comparable form to the year of 2003 using the consumer price index (CPI). Since there are no reliable deflators for fixed assets, the relative values of the stock of labor for each year are calculated.

\section{RESULTS AND DISCUSSION}

Statistical data on the income of the population, the distribution of the employed population by levels of education, by value of fixed assets, were taken from the reference books of the Federal State Statistics Service of the Russian Federation "Regions of Russia. Socio-economic indicators" for the period of 2003-2014. Regression "weighted", as the "weights" used variable "number of employed in the economy of the region population". In formula (2), human capital is the "average level of education" of one employed person in a region's economy or the "share of employed persons with higher education in the total number of employed persons in the region's economy", resulting in a variable "an average monthly income per an employed person".

TABLE I. INTERRELATION OF MONTHLY INCOME PER EMPLOYEE AND RELATIVE CAPITAL-LABOR RATIO, DENSITY OF EMPLOYMENT AND HUMAN

\begin{tabular}{|c|c|c|c|c|c|c|}
\hline \multirow{4}{*}{$\begin{array}{l}\text { Regression } \\
\text { indicators }\end{array}$} & \multicolumn{6}{|c|}{ Calculations (2), where $h_{i}$ is } \\
\hline & \multicolumn{3}{|c|}{ average education level } & \multicolumn{3}{|c|}{$\begin{array}{c}\text { share of employed with } \\
\text { higher education }\end{array}$} \\
\hline & \multicolumn{6}{|c|}{ Period } \\
\hline & $\begin{array}{c}2003- \\
2006 \\
\end{array}$ & $\begin{array}{c}2007- \\
2010 \\
\end{array}$ & $\begin{array}{r}2011- \\
2014 \\
\end{array}$ & $\begin{array}{c}2003- \\
2006\end{array}$ & $\begin{array}{l}2007- \\
2010\end{array}$ & $\begin{array}{r}2011- \\
2014\end{array}$ \\
\hline$A$ & $-8.611^{\mathrm{a}}$ & 2.125 & $1.576^{\mathrm{c}}$ & $7.138^{\mathrm{a}}$ & $8.086^{\mathrm{a}}$ & $8.494^{\mathrm{a}}$ \\
\hline Standard error & 2.587 & 1.613 & 0.875 & 0.298 & 0.279 & 0.175 \\
\hline T statistics & -3.320 & 1.317 & 1.801 & 23.941 & 29.027 & 48.640 \\
\hline$P$-value & 0.001 & 0.189 & 0.073 & 0.000 & 0.000 & 0.000 \\
\hline$\alpha$ & $0.636^{\mathrm{a}}$ & $0.431^{\mathrm{a}}$ & $0.378^{\mathrm{a}}$ & $0.790^{\mathrm{a}}$ & $0.464^{\mathrm{a}}$ & $0.423^{\mathrm{a}}$ \\
\hline Standard error & 0.062 & 0.037 & 0.035 & 0.057 & 0.034 & 0.036 \\
\hline $\begin{array}{l}\text { Standardized } \\
\text { regression } \\
\text { coefficients }\end{array}$ & $0.378^{\mathrm{a}}$ & $0.470^{\mathrm{a}}$ & 0.494 & $0.452^{\mathrm{a}}$ & $0.507^{\mathrm{a}}$ & $0.551^{\mathrm{a}}$ \\
\hline$T$ statistics & 10.395 & 11.736 & 10.896 & 13.918 & 13.787 & 11.827 \\
\hline$P$-value & 0.000 & 0.000 & 0.000 & 0.000 & 0.000 & 0.000 \\
\hline$\delta$ & $0.038^{\mathrm{b}}$ & $0.046^{\mathrm{a}}$ & $0.014^{\mathrm{a}}$ & $0.052^{b}$ & $0.030^{\mathrm{a}}$ & $0.036^{\mathrm{a}}$ \\
\hline Standard error & 0.015 & 0.009 & 0.003 & 0.015 & 0.011 & 0.005 \\
\hline $\begin{array}{l}\text { Standardized } \\
\text { regression } \\
\text { coefficients }\end{array}$ & $0.165^{b}$ & $0.267^{\mathrm{a}}$ & $0.181^{\mathrm{a}}$ & $0.231^{\mathrm{b}}$ & $0.177^{\mathrm{a}}$ & $0.452^{\mathrm{a}}$ \\
\hline$T$ statistics & 2.455 & 4.925 & 4.858 & 3.587 & 2.679 & 7.823 \\
\hline$P$-value & 0.015 & 0.000 & 0.000 & 0.000 & 0.008 & 0.000 \\
\hline$\gamma$ & $7.007^{\mathrm{a}}$ & $2.888^{\mathrm{a}}$ & $3.146^{\mathrm{a}}$ & $0.653^{a}$ & $0.466^{\mathrm{a}}$ & $0.350^{\mathrm{a}}$ \\
\hline Standard error & 1.034 & 0.635 & 0.335 & 0.108 & 0.094 & 0.047 \\
\hline $\begin{array}{l}\text { Standardized } \\
\text { regression } \\
\text { coefficients }\end{array}$ & $0.499^{\mathrm{a}}$ & $0.275^{\mathrm{a}}$ & $0.411^{\mathrm{a}}$ & $0.394^{\mathrm{a}}$ & $0.335^{\mathrm{a}}$ & $0.429^{\mathrm{a}}$ \\
\hline$T$ statistics & 6.779 & 4.545 & 9.380 & 6.071 & 4.944 & 7.449 \\
\hline$P$-value & 0.000 & 0.000 & 0.000 & 0.000 & 0.000 & 0.000 \\
\hline $\begin{array}{c}\text { The coefficient } \\
\text { of } \\
\text { determination } \\
R^{2}\end{array}$ & 0.810 & 0.825 & 0.730 & 0.803 & 0.828 & 0.697 \\
\hline $\begin{array}{l}\text { Fisher } \\
\text { criterion }\end{array}$ & 301.85 & 334.14 & 190.92 & 288.71 & 340.73 & 162.42 \\
\hline $\begin{array}{c}P \text { - value of the } \\
\text { criterion }\end{array}$ & 0.000 & 0.000 & 0.000 & 0.000 & 0.000 & 0.000 \\
\hline $\begin{array}{l}\text { Number of } \\
\text { regions }\end{array}$ & 216 & 216 & 216 & 216 & 216 & 216 \\
\hline
\end{tabular}
CAPITAL IN EUROPEAN REGIONS OF RUSSIA IN THE PERIOD OF 2003-2014 
Indicators of statistical reliability of all equations are quite high. The determination coefficients fluctuate around 0.7-0.8, Fisher's criterion is above 160. As it can be noted, the coefficient of income elasticity per employee in terms of relative stock of labor is approximately at the same level (see table. 1).

The total human capital represented by the variables "average level of education" and "share of employees with higher education" has a positive and statistically significant impact on the level of average monthly income. The impact of the variable "density of employment" on the income of the employed population is positive and statistically significant in both calculations and in all periods. The increase in the employment density by $1 \%$ corresponds to an increase in income per employee by about $0.02-0.04 \%$, therefore, the doubling of the employment density is accompanied by an increase in the income of the population by $2-4 \%$.

This fact seems to characterize the positive effect of the scale of production. There may also be a positive impact of a more developed social and productive infrastructure, as well as more intensive diffusion of knowledge and technology, in regions with higher population density. A. Ciccone estimates (1996) that doubling employment density increases productivity in developed countries by about 5\% (with a standard estimate error of $0.45 \%$ ) [18]. Similar estimates of agglomeration effects were obtained by P. Martin, G. Ottaviano, and F. Sbergami [6, 10].

As for the elasticity of income per employee in the average level of education, it is quite high in all periods. There is also a tendency to decrease it over time and for the regressor "share of employed with higher education", that is, apparently, the impact of human capital on income in Russia is falling. The coefficient of elasticity of income on the "share of employed with higher education" was lower than the coefficient of elasticity of income on the relative stock of labor, and on the "level of education" is significantly higher (table. 1).

Calculations of similar elasticities for another group of regions in the Urals, Siberian and Far East significantly differ from those already considered. These are the regions with more severe natural and climatic conditions of life, considerably lower density of the population and employment and essentially bigger share of raw branches of the national economy in total volume of production. All regression equations are statistically significant, as a rule, elasticity coefficients are statistically significant (table. 2).

The elasticities of income per employee in the relative capital-labor ratio in the second group of regions of Russia turned out to be about one and a half times lower than in the European regions, in both variants of calculations for all periods (table. 1 and 2). This fact testifies, apparently, to weaker influence of capital-labor ratio on the income of the population in the "Asian" part of Russia in comparison with the "European" one. In addition, the decrease in the elasticity of income per employed labor in the two groups of regions in the period under review can be explained by a decrease in the "quality" of fixed assets due to their increasing moral and physical wear and tear. It is known that investments in their renewal were during the considered periods obviously insufficient for their normal reproduction. The elasticity index of the variable "average monthly income" on the regression "the share of employed with higher education" for the "Asian" regions was statistically insignificant in all considered periods (table. 2). This phenomenon can be explained by the weak economic value of highly qualified human capital in regions with a predominance of raw material industries, relatively weak development of social infrastructure, as well as by the lower intensity of diffusion of knowledge and technology in regions with low population density.

TABLE II. THE RELATIONSHIP OF AVERAGE MONTHLY INCOME PER PERSON EMPLOYED RELATIVE CAPITAL-LABOR RATIO, DENSITY OF EMPLOYMENT AND HUMAN CAPITAL IN THE ASIAN REGIONS OF RUSSIA IN 2003 2014

\begin{tabular}{|c|c|c|c|c|c|c|}
\hline \multirow{4}{*}{$\begin{array}{c}\text { Regression } \\
\text { indicators }\end{array}$} & \multicolumn{6}{|c|}{ Calculations (2), where $h_{i}$ is } \\
\hline & \multicolumn{3}{|c|}{ average education level } & \multicolumn{3}{|c|}{$\begin{array}{l}\text { share of employed with } \\
\text { higher education }\end{array}$} \\
\hline & \multicolumn{6}{|c|}{ Period } \\
\hline & $\begin{array}{r}2003- \\
2006\end{array}$ & $\begin{array}{l}2007- \\
2010\end{array}$ & $\begin{array}{c}2011- \\
2014\end{array}$ & $\begin{array}{l}2003- \\
2006\end{array}$ & $\begin{array}{l}2007- \\
2010\end{array}$ & $\begin{array}{c}2011- \\
2014\end{array}$ \\
\hline$A$ & 2.721 & $5.675^{\mathrm{a}}$ & $3.499^{\mathrm{a}}$ & $8.927^{\mathrm{a}}$ & $9.305^{\mathrm{a}}$ & $9.387^{\mathrm{a}}$ \\
\hline Standard error $\mathrm{T}$ & 3.176 & 1.907 & 1.170 & 0.439 & 0.381 & 0.431 \\
\hline statistics & 0.857 & $2.975^{\mathrm{a}}$ & 2.992 & 20.342 & 24.410 & 21.774 \\
\hline$P$-value & 0.394 & 0.004 & 0.004 & 0.000 & 0.000 & 0.000 \\
\hline$\alpha$ & $0.322^{\mathrm{a}}$ & $0.281^{\mathrm{a}}$ & $0.218^{\mathrm{a}}$ & $0.340^{\mathrm{a}}$ & $0.293^{\mathrm{a}}$ & $0.240^{\mathrm{a}}$ \\
\hline Standard error & 0.040 & 0.027 & 0.021 & 0.040 & 0.026 & 0.023 \\
\hline $\begin{array}{l}\text { Standardized } \\
\text { regression } \\
\text { coefficients }\end{array}$ & $0.612^{\mathrm{a}}$ & $0.743^{\mathrm{a}}$ & $0.653^{\mathrm{a}}$ & $0.647^{\mathrm{a}}$ & $0.774^{\mathrm{a}}$ & $0.721^{\mathrm{a}}$ \\
\hline$T$ statistics & 8.087 & 10.486 & 10.369 & 8.477 & 11.087 & 10.289 \\
\hline$P$-value & 0.000 & 0.000 & 0.000 & 0.000 & 0.000 & 0.000 \\
\hline$\delta$ & $-0.034^{b}$ & 0.005 & $0.010^{\mathrm{a}}$ & $-0.031^{\mathrm{c}}$ & 0.009 & 0.012 \\
\hline Standard error & 0.016 & 0.012 & 0.003 & 0.017 & 0.012 & 0.009 \\
\hline $\begin{array}{l}\text { Standardized } \\
\text { regression } \\
\text { coefficients }\end{array}$ & $-0.159^{b}$ & 0.031 & $0.240^{\mathrm{a}}$ & $-0.144^{c}$ & 0.053 & 0.298 \\
\hline$T$ statistics & -2.109 & 0.451 & 3.705 & -1.783 & 0.748 & 1.403 \\
\hline$P$-value & 0.038 & 0.653 & 0.000 & 0.078 & 0.456 & 0.164 \\
\hline$\gamma$ & $2.640^{\mathrm{b}}$ & $1.589^{\mathrm{b}}$ & $2.418^{\mathrm{a}}$ & 0.161 & 0.136 & 0.104 \\
\hline Standard error & 1.250 & 0.745 & 0.453 & 0.139 & 0.118 & 0.126 \\
\hline $\begin{array}{l}\text { Standardized } \\
\text { regression } \\
\text { coefficients }\end{array}$ & 0.150 & $0.141^{\mathrm{b}}$ & $0.354^{\mathrm{a}}$ & 0.086 & 0.077 & 0.176 \\
\hline$T$ statistics & 2.113 & 2.132 & 5.339 & 1.154 & 1.147 & 0.827 \\
\hline$P$-value & 0.037 & 0.036 & 0.000 & 0.252 & 0.252 & 0.410 \\
\hline $\begin{array}{c}\text { The coefficient } \\
\text { of }\end{array}$ & 0.547 & 0.612 & 0.638 & 0.532 & 0.599 & 0.534 \\
\hline determination $R^{2}$ & & & & & & \\
\hline Fisher criterion & 38.593 & 50.454 & 56.444 & 36.39 & 47.805 & 36.68 \\
\hline $\begin{array}{c}P \text { - value of the } \\
\text { criterion }\end{array}$ & 0.000 & 0.000 & 0.000 & 0.000 & 0.000 & 0.000 \\
\hline $\begin{array}{l}\text { Number of } \\
\text { regions }\end{array}$ & 100 & 100 & 100 & 100 & 100 & 100 \\
\hline
\end{tabular}

The migration of skilled workers from the Eastern regions of Russia to more comfortable regions of the European part of Russia may also play a role. Of the 25 regions of the Asian part of Russia included in the calculation, only 5 (Sverdlovsk, Tyumen, Novosibirsk, Tomsk regions and Krasnoyarsk territory) in recent years (2001-2015) showed a positive coefficient of migration growth. Thus, the sustainable development of the territories of Russia due to the diffusion of knowledge is more ensured in the first group of the considered regions. 


\section{CONCLUSION}

A sharp contrast to the Asian regions of Russia from the European manifests itself in the values of the coefficients of the elasticity of revenues per one employee in the human capital. This is due to the positive impact of agglomeration (and related) effects on labour productivity and income in more densely populated European regions. It can be assumed that the intensity of knowledge diffusion in the Asian regions of Russia is lower, therefore, the accumulation of human capital is ineffective and does not affect income generation. This is an extremely unpleasant signal, indicating, apparently, that the enterprises of the raw materials sector, prevailing in these regions, do not demand human capital of the highest category. It can be concluded that in most raw material regions of Eastern Russia, human capital is not used effectively enough, which is manifested in the spontaneous process of migration of the population from the Eastern regions of Russia to the Western ones, as well as from rural regions to urban agglomerations.

This situation cannot be considered normal, so we can suggest creating a system of incentives for attracting and retaining highly qualified specialists in the Eastern regions of Russia, improving the education system and ensuring sustainable development of these regions to reverse this negative trend. It can be assumed that the modernization of regional universities and colleges in relatively sparsely populated regions of the Urals, Siberia and the Far East and the introduction of information and communication technologies will contribute to the intensification of the diffusion of knowledge and technology in these regions and thereby accelerate sustainable development.

\section{References}

[1] E. Pelinescu "The impact of human capital on economic growth," Procedia Economics and Finance, vol. 22, pp. 184-190, 2015.

[2] L. Wantchekon, M. Klašnja and N. Novta "Education and human capital externalities: evidence from colonial Benin," The Quarterly Journal of Economics, vol. 130(2), pp. 703-757, 2014.

[3] A.A.C. Teixeira and A.S.S. "Queirós Economic growth, human capital and structural change: A dynamic panel data analysis," Research Policy, vol. 45(8), pp. 1636-1648, 2016.
[4] K. Laursen, T. Reichstein and A. Salter "Exploring the effect of geographical proximity and university quality on university-industry collaboration in the United Kingdom," Regional studies, vol 45(4), pp. 507-523, 2011.

[5] V. Tselios, A. Rovolis and Y. Psycharis Regional Economic Development, Human Capital and Transport Infrastructure in Greece: The Role of Geography in Regional Upgrading in Southern Europe, Cham: Springer International Publishing, 2017, pp. 151-174.

[6] F. Sbergami Agglomeration and Economic Growth: Same Puzzles, HEI Working Paper No. 02/2002, 2002, pp. 1-34.

[7] A. Faggian and P. McCann "Human Capital Flows and Regional Knowledge Assets: A Simultaneous Equation Approach," Journal Oxford Economic Papers, vol 58, pp. 475-500, 2006.

[8] B. Abbott and G. Gallipoli "Human Capital Spillovers and the Geography of Intergenerational Mobility," Review of Economic Dynamics, vol. 25, pp. 208-233, 2017.

[9] I. Eaton and S. Kortum "Trade in Ideas: Productivity and Patenting in OECD," Journal of International Economics, vol 40, pp. 251-278, 1996.

[10] P. Martin and G. Ottaviano "Growth and Agglomeration," International Economic Review, vol. 42, pp. 947-968, 1991.

[11] P.J. Klenow and A. Rodriguez-Clare "Economic growth: A review essay," Journal of monetary economics, vol. 40(3), pp. 597-617, 1997.

[12] A.A. Aletdinova and M.A. Bakaev "The economy of smart and AIbased education," The Social Sciences, vol 11(21), pp. 5151-5156, 2016.

[13] C. Goldin and L.F. Katz "The legacy of US educational leadership: Notes on distribution and economic growth in the 20th century," The American Economic Review, vol. 91(2). pp. 18-23, 2001.

[14] D. Mitch "The Rise of Mass Education and Its contribution to economic Growth in Europe, 1800-2000," Fourth European Historical Economics Society Conference. Oxford: Merton College, 2001.

[15] A. Young "The tyranny of numbers: confronting the statistical realities of the East Asian growth experience," The Quarterly Journal of Economics, vol. 110(3), pp. 641-680, 1995.

[16] R.E. Lucas Lectures on economic growth [Lektsii po ekonomicheskomu rostu]. Moscow: Publishing house of Gaidar Institute, 2013, p. 281.

[17] C.I. Jones "R \& D-based models of economic growth," Journal of political Economy, vol. 103(4), pp. 759-784, 1995.

[18] A.V. Koritsky and V.A. Semenikhina "Evaluation of the influence of population density and the size of regional markets on wages and incomes in the regions of Russia [Otsenka vliyaniya plotnosti naseleniya i razmerov regional'nykh rynkov na urovni zarabotnoy platy i dokhodov v regionakh Rossii]," We continue the traditions of Russian statistics [My prodolzhayem traditsii rossiyskoy statistiki], Novosibirsk: Publishing house of NGUEC, vol. 4, pp. 106-111, 2016.

[19] A. Ciccone "Agglomeration - Effects in Europe," 1999, Url: https://papers.ssrn.com/sol3/papers.cfm?abstract_id=243775, Accessed 11.11.2017 